\title{
HOW TO WRITE YIDDISH IN ENGLISH, OR ISRAEL ZANGWILL AND MULTILINGUALISM IN CHILDREN OF THE GHETTO
}

JESSICA R. VALDEZ

In 1888, an Orthodox English-language newspaper, the Jewish Standard, published an article series, "Jews in Fiction," that looked critically at Jewish characters in English literature. The series began with Sir Walter Scott's Isaac of York, then featured Benjamin Disraeli's Sidonia and George Eliot's Daniel Deronda. After critiquing Fagin and Riah, the April 20th column conjectured what it might look like for Charles Dickens to use his "magician's wand" to write a more nuanced treatment of everyday Jewish life:

\begin{abstract}
How he would have reveled in the description of the ostentation, the generosity, the kindliness, the harshness, the thousand and one contradictions to be found in our fellow-Jews and Jewesses. [How he would have treated]... Mr. and Mrs. Z-, with all their children - how they went to synagogue Saturday morning gorgeously attired.... Then Dickens would describe how the family go home to luncheon, a better luncheon most likely than on weekdays, because paterfamilias is at home. How our author would revel over the fried fish and various orthodox dainties. (3)
\end{abstract}

Envisioning Jewish life through the lens of an outside observer, the columnist's flight of fancy focuses more on the imagined pleasure Dickens would take in the spectacle, how he would "revel" in the scene, than on the interior lives of the Jewish characters. The writer then exclaims, "Shade of Dickens! would that your mantle might descend on my shoulders, that I might worthily describe all this." The irony is, of course, that the writer has just described this scene, but as the imagined Dickens.

This passage from the Jewish Standard dramatizes the pressure of external Jewish stereotypes on the self-conception of the nineteenth-century AngloJewish community. In the very act of portraying this community, the columnist negates the act by calling upon Dickens to make the anonymous columnist a 
worthy narrator for depicting Jewish life. On one level, this negation seems to present an ambivalence about the potential for Jewish authorship and literature. Yet the writer also imagines Dickens relishing the material culture of AngloJewish life and finding charm in its difference from the English everyday: the synagogue, the fried fish, the "orthodox dainties." The writer in effect calls for a Jewish Dickens, a persona that is both English and Jewish.

At the time of this column's printing, Israel Zangwill - the man who would later be called the "Jewish Dickens"-was subeditor of the Jewish Standard and writing a satiric column about Anglo-Jewish life called "Morour and Charouseth." Born to immigrants from czarist Russia in 1864 and raised in London's East End, Anglo-Jewish writer Israel Zangwill became famous for his realistic depiction of Jewish East End life in his 1892 novel Children of the Ghetto: A Study of a Peculiar People, which was considered the foremost representation of Jewish life in both Great Britain and the United States. Zangwill was a transatlantic celebrity in his time and a political activist in the international Jewish community. He has, however, been largely marginalized in the twentieth and twenty-first centuries, arguably in the first instance because of his opposition to a Jewish state in Palestine. Critic Meri-Jane Rochelson has worked to correct misconceptions about Zangwill and to make him a central figure of Victorian studies. In A Jew in the Public Arena, Rochelson critiques scholars like Joseph Udelson who reduce Zangwill's world view to one divided between assimilation in the West and Orthodoxy elsewhere. She also critiques readings that represent tensions and inconsistencies in Zangwill's work as evidence of his ambivalence toward his Jewish identity. Instead, she sees these inconsistencies as a pragmatic response to lived situations: she writes, "By insisting upon both sides of his identity, his Jewishness and his Englishness, Zangwill made choices that are indeed emblematic of those faced by many in his generation and later..." (Jew in the Public Arena 4). In this paper, I agree with Rochelson's reluctance to read Zangwill's tensions around Jewish and English identity as representative of some psychological ambivalence about his status as an Anglo-Jew. However, I want to consider the linguistic elements of Zangwill's relationship to identity, in particular his movement between Yiddish, Hebrew, and English language and literary traditions. Sander Gilman has claimed that languages such as Yiddish and Hebrew marked Jews as different from mainstream Europe and contributed to the perception of their otherness (308). Although many nineteenth-century novelists, most notably Dickens, used dialect to distinguish certain characters, Zangwill's use of Yiddish, Hebrew, and English highlights the extent to which meanings and contexts are not portable across languages. In Children of the Ghetto, Zangwill brings the multilingualism of most nineteenth-century Yiddish speakers to a novel written predominantly in English. Zangwill's writing not only thematizes how language marks hybrid otherness, I argue, but also works within both the Yiddish and English literary traditions in Children of the Ghetto. 
This essay thus breaks with an essentialist position held by Joseph Childers and many other critics and historians who argue that, because Englishness as an identity is contradictory, "the Jews are also never completely English" (Childers 219). In analyzing Children of the Ghetto, Childers insists that individuals tend to identify more or less with a particular discourse and identity; they cannot be both English and Jewish since these identities and discourses are in tension. He concludes, "At the very least, this novel makes it apparent that participating in both Englishness and Jewishness may increase the number of possible subject positions available to the characters of this book, but there is no place of compromise that allows a subject to be completely English and completely Jewish" (222). I argue, however, that Zangwill's novel problematizes compartmentalized Jewish and English identities in order to foster a tenuous intermingling. Even as Zangwill feels a wistful nostalgia for an authentic Jewishness, his novel advocates for what approximates a hybrid of the two identities in the figure of Esther, who grows up in the East End, becomes socialized in the West End, and later emigrates to America. She represents the melting pot, a term that Zangwill later coins, rather than being one-dimensionally Jewish or English.

As Zangwill is in conversation with different traditions of English realism, he shows the influence of a new eastern European Yiddish literature. At a time when novelists are interpreting realism in more fatalist modes - such as George Gissing —or rejecting realism in favor of proto-modernist aestheticism, Zangwill recuperates a mid-century realism that adheres to George Eliot's theory pronounced in Adam Bede, in which she argues for realism's capacity to cultivate sympathy in readers for "the real breathing men and women, who can be chilled by your indifference or injured by your prejudice; who can be cheered and helped onward by your fellow-feeling, your forbearance, your outspoken, brave justice" (166). At the same time, Zangwill critiques Eliot's adoption of mysticism as a means to represent the Jewish question in Daniel Deronda. Like his Yiddish contemporaries, Zangwill rejects Eliot's mysticism in favor of mimetic realism imbued with elements of romance and melodrama.

Throughout this analysis, I also intend to provide a critique of Gilles Deleuze and Felix Guattari's Kafka: Toward a Minor Literature. Deleuze and Guattari argue that minor cultures create their own literatures in a language associated with another national imaginary. They read Kafka as a deterritorialized writer who takes on imperial language in order to subvert and reappropriate it for revolutionary purposes. Ruth R. Wisse has argued that Deleuze and Guattari read Kafka against the grain and misinterpret his sense of privilege to be writing in a dominant language; instead, she argues, Kafka used the term "minor literature" to refer to literature written within a minor language like Yiddish. Rather than seeing Jewish literature as a minor literature, Wisse argues that Jewish writers knowingly straddled two cultures and belonged to two literary traditions, even apparently antithetical traditions like Yiddish and German (87). ${ }^{2}$ 
Contrary to Deleuze and Guattari's reading of minor literature, and similarly to Wisse's approach, I argue that Zangwill works in both the English and Yiddish literary traditions rather than using the dominant language in order to subvert it. He adopts English language and form, but he also invests it with references to Jewish history and culture as well as Yiddish literary mimetic tradition.

\section{Representing the Anglo-Jewish Condition}

Zangwill's novel features a heroine who grows up in the Jewish East End and later becomes the anonymous author of a realist novel, Mordecai Josephs. Esther Ansell's novel, written under the name of Edward Armitage, presents a searing portrayal of the materialist, status-oriented Jewish West End, where she lives after being adopted by a wealthy Jewish family. Esther's novel is widely criticized for realistically portraying Anglo-Jews rather than providing an idealized and assimilated portrait of West End Anglo-Jews. By situating a realist writer at the core of his novel, Zangwill interrogates the representative and aesthetic dilemma at the center of the Anglo-Jewish condition: how to represent a necessarily hybrid identity and write for both a Jewish audience and a less sympathetic general English audience.

Characters in Children of the Ghetto reject Esther's form of realism because it presents a self-critical portrayal of the Jewish community. They highlight the importance of tailoring such representations for the benefit of the non-Jewish reader. When discussing Mordecai Josephs over dinner at the Goldsmiths' house (where the adopted Esther now lives), characters point out, "Yes, the book's true enough," but add, "[i]t's plain treachery and disloyalty, this putting of weapons into the hands of our enemies" (329). Although alive to the novel's authentic portrayal of Jewish life, these characters perceive the novel as disloyal because of its refusal to advocate for the Jewish community against English stereotypes. What they want is an idealized, anglicized portrayal of Anglo-Jewish community, one that glosses over the cultural differences that distinguish them (particularly the new immigrants) from their English counterparts. These characters approach the novel through the perspective of an English reader, and they filter their reactions through the mainstream reader's imagined responses. As a result, they consider the novel's use of Yiddish- " jargon"- to be an affront to the community's efforts to intermingle with English society. Although the characters make clear that it is OK to joke about their community behind closed doors, even in terms of stereotypes, it becomes reprehensible when a member of the community sounds as though he or she is confirming the stereotype for outsiders. Indeed, when it emerges that Esther is the author of the despised novel, she is accused of treachery. For these characters, aesthetic representation of Anglo-Jewish life should shy away from realism in order to provide a sanitized, anglicized version. ${ }^{3}$

Painter and aesthete Sidney Graham (whose real name is Abrahams) responds to this pressure by abandoning his identification with a Jewish 
community. In a Wildean conversation with the novel's main character Esther, Sidney explains his refusal to call himself a Jew:

[I]t would be a lie to say I was. It would be to produce a false impression. The conception of a Jew in the mind of the average Christian is a mixture of Fagin, Shylock, Rothschild and the caricatures of the American comic papers. I am certainly not like that, and I'm not going to tell a lie and say I am. In conversation always think of your audience. It takes two to make a truth. If an honest man told an old lady he was an atheist, that would be a lie, for to her it would mean he was a dissolute reprobate. (Zangwill 390)

Sidney articulates himself within the framework of English literature and, rather than creating a minor literature, abandons his Jewish identity in order to conform to English and Christian mainstream assumptions. At the core of Sidney's argument is an aesthetic denial of reality outside art. He denies the external truth of a Jew and suggests the identity is only socially and culturally constructed. He also questions realism's capacity to represent mimetically in the midst of social and literary stereotypes and tropes. As I will explain later in this essay, Zangwill's project of novelistic realism rejects this ambivalent aestheticism and asserts the tangible reality of Anglo-Jewish life.

In depicting these different responses to realism, Zangwill dramatizes the representational question central to the Anglo-Jewish situation, both politically and aesthetically. The situation of Anglo-Jews differed dramatically from their European counterparts; their position in Britain was characterized by what Bill Williams has called an "anti-Semitism of tolerance." By the late nineteenth century, Anglo-Jews had won new political rights and could serve in Parliament. However, they also felt pressured to represent themselves as a unified religious community consistent with the lifestyle of the English middle class. The literary trope of Shylock, the unyielding usurer, persisted in popular depictions of the Jewish community. Anglo-Jewish writers persistently articulated the difficulties posed by these stereotypes, which by the end of the century were bolstered by the purported evidence of pseudo-sciences like phrenology. ${ }^{4}$ Jewish artists could not represent their community without taking into account the competing representations produced by non-Jewish writers. Many Jewish writers reflected these stereotypes: In 1888, Amy Levy wrote the controversial novella Reuben Sachs in which she castigates the middle-class Jewish community for its alleged materialist and racial decline. Anglo-Jews were generally interpreted and understood "via the discursive construct of 'the Jew'. More strikingly than ever, 'the Jew' was overdetermined: infinitely wealthy and yet abjectly poor; refusing to assimilate and yet assuming a false English identity; cosmopolitan and trivial; alien and yet almost overly familiar..." (Bar-Yosef 3).

At the core of this representational question is George Eliot's novel Daniel Deronda. Published sixteen years after Daniel Deronda, Children of the Ghetto 
openly engages with Eliot's novel and critiques the perceived unreality of its Jewish characters. Most contemporary critics have read Daniel Deronda as two novels - the realist English plot and the romantic Jewish plot. Sarah Gates has argued that Daniel Deronda demonstrates a loss of faith in the realist form:

\begin{abstract}
Whereas in Eliot's earlier fiction the force of realism acts as a kind of demystification of the energies produced by, for example, romance or pastoral in order to rein them in to the stable domestic closures that constitute the transcendent endings traditional to English realism, in Deronda Eliot adds the weightier energies of epic and tragedy to the kinds of romance that have directed so many of the stories in her earlier works, and so doing stretches that force beyond its capacity to perform this demystifying and domesticating function. (Gates 699)
\end{abstract}

Similarly, Franco Moretti has famously argued that Eliot's change in formwhat he considers the failure of Daniel Deronda - is because Eliot's genre, the bildungsroman, can no longer function as a symbolic form of its age (227). Whereas the bildungsroman retains its faith in the individual's ability to develop according to his own nature, the collectivist nature of Eliot's sympathy to Jewish nationalism requires a split with the realist novel's valorization of individualism for Moretti.

Zangwill offers another means of understanding bildung and realism in relation to the Jewish question. Whereas Moretti highlights the symbolic failure of bildung, and Gates emphasizes the realist novel's limiting capacity to demystify and domesticate, Zangwill uses a nostalgic realism in the novel's first book and bildung in the second book as means of representing the problem of Jewish representation. Zangwill provides a central character, Esther Ansell, who forges a sense of liberal individuality in tandem with her obligations to the Jewish community. In fact, Zangwill's novel openly critiques and rewrites versions of Daniel Deronda and problematizes the timeless quality of Eliot's Jewish plot. During a conversation in Children of the Ghetto, the West End characters contrast Mordecai Josephs with Daniel Deronda in terms of AngloJewish representation. Esther's love interest, Raphael Leon, feels that Eliot idealizes the Jewish characters, and Sidney insists, "there is more actuality in [Mordecai Josephs] than in Daniel Deronda" (331). This critique of Eliot is also embedded in the very fabric of the novel, with characters loosely paralleling those of Eliot's novel, and with meaningful gaps in the parallel. Deronda's character is spread across Esther and Raphael, in order to suggest the limitations of Raphael's middle-class and idealist perspective of Jewish life in contrast to the far more integrated experience of Esther. In this way, Eliot's suggestion that realism is not capacious enough to represent the position (or dis-position) of the Jew in a liberal state comes under critique. Nor does Zangwill fall back on the kind of mysticism espoused by Mordecai in Eliot's novel; in fact, Mordecai's character is omitted from the novel, and his absence 
is emphasized by the allusion in the title of Esther's novel. Instead, Zangwill follows the earlier realist tradition of Eliot and the newly emerging tradition of Yiddish literature, which relied substantially on anthropological realism with the goal of educating its readers. Zangwill recuperates the realist form of Children of the Ghetto in a way that links both English and Yiddish realism. I will unpack this claim by first looking at the form of Yiddish and its presence in the novel, then the close resemblance of Children of the Ghetto to Yiddish literature of the period.

\section{A Jewish Robert Elsmere}

In 1888, the American Jewish Publication Society conscripted Zangwill to write a "Jewish Robert Elsmere," based on a novel by Mrs. Humphry Ward (Mary Ward) about an Oxford clergyman who comes to doubt the Anglican Church and takes up instead "constructive liberalism," that is, social work among the East End poor. This conscription suggests the extent to which the Jewish population, in both England and America, felt excluded by the novel's story of individual spiritual awakening. However, as Naomi Hetherington has argued, Children of the Ghetto little resembles Robert Elsmere; rather than focusing on individual rebirth, Zangwill depicts the lifestyle of a whole people and the erosion of their practices as a result of mainstream cultural pressure. ${ }^{5}$ In the first book, Zangwill depicts a loose web of characters yoked together by geography and identity. In a handwritten author's note on the novel's typescript, he penned, "the aim of this book is less to tell a story than to paint a community" (Jew in the Public Arena 69). The first book privileges an anthropological mode of realism that provides a broad social critique. The second book focuses more exclusively on Esther Ansell, who now lives in the West End and goes through a crisis of identity.

The novel's first book, although written in English, echoes the conversational and associative structure of Yiddish. Many Yiddish texts are structured around what Benjamin Harshav calls "associative talking," the most obvious example being Tevye the Dairyman. Harshav writes,

In this mode the small units of language and thematic motifs are not strung on one narrative string and made subordinate to the unfolding of plot or an architectonic structure, but are relatively independent and episodic....At the same time, such a unit clashes with and relates to its discontinuous neighbors, creating mutual reinforcement, semantic density, stylistic play, and irony in this tangle. (Harshav 153)

Children of the Ghetto mimics the form described by Harshav; Zangwill moves associatively from one character sketch to another and through contrast develops his playful, ironic commentary, a style he previously perfected in his column for the Jewish Standard. ${ }^{6}$ For instance, Zangwill introduces the reader to the Belcovitch family when Esther's spilled soup leaks through the cracks 
of the floor into the apartment below. The reader follows the spilled soup to see Becky Belcovitch surrounded by her undesired suitors. The narrative movement is not linear but spatial; the reader moves from one room to another in the small London tenement house. The scenes also occur simultaneously, creating a sense of a shared East End community commensurate with Benedict Anderson's theories about the novelistic cultivation of communal feeling. It juxtaposes the small tragedy of Esther's lost soup with the comedy of a vain girl surrounded by unwanted suitors. This associative organization mimics Zangwill's earlier Jewish Standard column, "Morour and Charouseth," which plays with generic boundaries to bring out a satire of Anglo-Jewish society contrasted with the hardship faced by immigrant Anglo-Jews. The column relates impressions of everyday encounters and stories; it contains retellings of biblical stories, rumors, news of interest, jokes, and poetry. Zangwill mingles reports about tensions between the mainstream Jewish community and socialists with humorous stories whose punch lines toy with Yiddish. In one column, he even playfully conceals his identity by speaking in third person about an author named "I. Zangwill," an author so unknown to the public, he says, his name is continually mispronounced and misremembered in the media. The column is divided up into short sections, and Zangwill develops his satire through contrast and contextualization. He uses a similar practice of ironic contrast in Children of the Ghetto, particularly a contrast of London geography and social class. This associative form relies on linguistic double meaning and the playful movement between different voices, genres, and even languages to convey satire. Zangwill also emphasizes the cultural loss threatened by a reduction in this kind of linguistic complexity and contrast.

In contrast, Zangwill's novel highlights the sacrifice of meaning and community as multilingualism is replaced by the monolingual dominance of English language and culture. The first book examines the generational divide between the older generation of immigrants and their children, who seek to break from Jewish practices to become more English. The new generation absorbs portrayals of Jews as archaic and premodern, and they abandon many of the practices of Orthodox Judaism and the Yiddish language. In their view, to become modern is to become English. While a child, Esther is aware of her Jewish identity because of the "scoffing rhymes of Christian children," but she is more deeply aware of her Englishness:

But far more vividly did she realize that she was an English girl; far keener than her pride in Judas Maccabaeus was her pride in Nelson and Wellington; she rejoiced to find that her ancestors had always beaten the French from the days of Cressy and Poictiers to the days of Waterloo, that Alfred the Great was the wisest of kings, and that Englishmen dominated the world and had planted colonies in every corner of it, that the English language was the noblest in the world and men speaking it had invented railway trains, steamships, telegraphs, and everything worth inventing. Esther absorbed these ideas from the school reading books. (152) 
Zangwill ironically suggests the imaginary quality of historical and national background, the extent to which partial inclusion creates a divided self that isn't Jewish or English. Through Esther, the novel depicts the competition between English modes of instruction and those of immigrant culture. Characters like Esther's aunt Malka oppose the English schools because "it's English, not Judaism, they teach them in that godless school" (102-03). Childers cites this same passage to argue on behalf of the irreconcilable nature of English and Jewish identity in the novel. According to Childers, Esther can choose only one or the other, and here she chooses to associate with Englishness. However, it's important that this scene happens early in the novel during Esther's childhood, and as a result of her one-sided English education. Although Zangwill satirically treats Esther's sense of absolute Englishness, he does not align himself with Malka's absolute resistance to anglicization. Instead, Zangwill suggests the importance of both influences.

Set in contrast to Esther's English schooling, her father Moses offers an alternative history through the practice of oral storytelling. One evening Moses Ansell tells his children a story in Yiddish "about the Emperor Nicholas [that] is not to be found in the official histories of Russia" (158). In this story, Nicholas I threatens to drive the Jews out of their homes. When offers of reparation fail, the "Masters of Cabalah" call upon the spirits of Abraham, Isaac, Jacob, and Elijah the prophet, who "took Nicholas the Emperor out of his warm bed and whipped him so soundly that he yelled for mercy" (158). Nicholas finally annuls the edict for the Jews' expulsion after being repeatedly "drubbed" by the spirits. Moses's story contradicts the official history of Russia and empowers the Jewish people against the tyranny of mainstream power. Storytelling offers Moses and his children a means of empowerment against dominant cultures and a sense that they are a people with a long history. Even as the use of Yiddish is in decline, Zangwill's realist novel conveys the impression of an oral story and thereby preserves Jewish culture through novelistic realism. Sander Gilman has claimed that languages such as Yiddish and Hebrew marked Jews as different from mainstream Europeans and therefore construed them as suspect. By contrast, Zangwill suggests the importance of Yiddish in allowing the Anglo-Jewish community to retain their identity while also participating in an English culture.

It is particularly essential that Moses tells his story in Yiddish. Zangwill highlights his characters' multilingualism, whether through the use of Yiddish or Hebrew words, or through syntactical signals in English. When the original publisher asked him to include a glossary of Yiddish terms, Zangwill resisted and acceded only for later editions, still refusing to write it himself. This resistance suggests that he thought that Yiddish could not be properly translated into English, and that the novel was playing with the possibilities and impossibilities of translation. As Rochelson highlights in her essay, "A Religion of Pots and Pans," Zangwill "reproduces, celebrates and undercuts" Jewish 
forms of discourse. She writes, "Yet when Yiddish is translated into English in the novel it is done literally, rather than idiomatically, making a rich and vital language sound archaic, almost reminiscent of the King James Version, yet allowing the occasional intrusion of vulgar metaphor" (123). I want to expand upon Rochelson's claim here and argue that Zangwill represents Yiddish and Hebrew in three different modes: used directly and accompanied with a translation, used directly without a translation, or represented as that language yet written in English. Zangwill carefully signals when characters switch between languages, even if these languages are represented in the English language. As Rochelson mentions, Yiddish is often depicted in an English that uses Yiddish grammar and syntax. This English-Yiddish hybrid alienates both Yiddish and English-speaking readers, since the Yiddish grammar makes the dialogue sound archaic, particularly through the word "thou." I would add that Zangwill's refusal to anglicize Yiddish grammar in these English translations highlights the untranslatability of certain elements of language. Yiddish functions differently from Hebrew and English in the lived experience of Yiddish speakers. Zangwill maintains this linguistic contextualization by retaining grammatical signifiers from each language. For instance, he mimics the characters' shift in languages by making changes in syntax: when Reb Shemuel's wife worries that he gives away all their money, she says:

"For thy salvation do I hope, O Lord," murmured Simcha piously in Hebrew, adding excitedly in English, "Ah, you'll kill yourself, Shemuel.... Here, you fool, you've been and done a fine thing this time! All your silver was in the coat you've given away!"

"Was it?" said Reb Shemuel, startled. Then the tranquil look returned to his brown eyes. "No, I took it all out before I gave away the coat."

"God be thanked!" said Simcha fervently in Yiddish. "Where is it? I want a few shillings for grocery."

"I gave it away before, I tell you!"...

"Here's the end of the week coming," she sobbed, "and I shall have no fish for Shabbos."

"Do not blaspheme!" said Reb Shemuel, tugging a little angrily at his venerable beard. "The Holy One, blessed be $\mathrm{He}$, will provide for our Shabbos."

Simcha made a sceptical mouth, knowing that it was she and nobody else whose economies would provide for the due celebration of the Sabbath. (133)

Zangwill flags for the reader Simcha's shifts between Yiddish, Hebrew, and English; but he also reflects the change in both the syntax of the sentences and the emotion Simcha expresses. Although the entire dialogue is conveyed in English, Zangwill mimics the syntax of Hebrew and Yiddish, so that Simcha's statements are missing articles and other grammatical elements necessary to English-for instance, "a few shillings for grocery." Simcha uses Hebrew to appeal to God on Reb Shemuel's behalf, then shifts to English to nag her husband, and finally falls into Yiddish to express her misplaced relief about the 
lost money. Similarly, Reb Shemuel's syntax suggests that he is speaking in Hebrew when he remonstrates his wife. The shift in language reveals a tension between the husband's idealizing stance that God will provide and the wife's practical sense that she must provide. At one level, Simcha's shift between languages signals the tensions between supporting her family in the western world and still adhering to what Zangwill considers to be a separatist vision of Judaism, embodied particularly in Reb Shemuel. However, the movement between languages also signifies the everyday reality of most Yiddish speakers in this period.

Yiddish is traditionally a language used by multilingual speakers and contains various linguistic and historical references; it uses German, Hebrew, and Aramaic components, although it also contains other influences. Harshav highlights that often two source languages clash in one utterance to create irony and multi-level meanings: "This is what Yiddish is all about: the individual words may be very simple but their interaction-involving pieces of texts and divergent languages and cultural situations rather than mere lexical denotations - makes it rich, ironic, plurisignifying" (36). The mingling of source languages and their traditional association enables a far richer means of expression than can be conveyed by a single language: "In Yiddish, one can speak several languages in the same sentence" (Caplan 9). This spatial and stylistic juxtaposition mimics the imbrication of English, Yiddish, Hebrew, and even implied German in the novel. In this excerpt, Reb Shemuel and Simcha speak several languages implied by the text's English, and their linguistic shifts signal additional levels of meaning to the reader.

As characters become monolingual and anglicized, they are unable to participate in the world of the older generation. Zangwill depicts the poignancy of this generational gap by representing unspoken thought in the form of dialogue. The Hyamses, a family composed of an elderly couple and their adult children, show the misconceptions and communicative failures that inhibit their mutual understanding. Daniel Hyams knows he cannot marry the woman he loves because he must support his aging parents and thus refuses to attend a bar mitzvah where he would be forced to see his would-be lover. But he disguises his reasons for declining the invitation when talking to his parents, claiming he simply has a conflicting obligation.

\footnotetext{
It was a superfluous lie for so silent a man.

"He doesn't like to be seen with us," Beenah Hyams thought. But she was silent.

"He has never forgiven my putting him to the fancy goods," thought Mendel Hyams when told. But he was silent. (169)
}

Displayed as a dialogue, these misunderstandings are particularly moving because they are apparent only to the reader and are not communicated between characters. The inner isolation is expressed exactly at these moments 
when plot and spoken dialogue are suspended. This scene sets up a contrast to the richness of the Yiddish, Hebrew, and English interaction between Reb Shemuel and Simcha. Where these characters communicate richly in ways that even they cannot understand, the Hyamses are silenced by their generational, linguistic, and cultural difference.

Similarly, Esther's older brother, Benjamin Ansell, loses access to his personal history and childhood memories through his conversion to monolingualism. Forgetting most of his Yiddish while away at school, he is unable to communicate with the older members of his family when he visits home. Benjamin's inability to speak or understand Yiddish separates him from his family and from memories of his childhood, which the novel highlights as so important to Esther's formation as a character and a novelist herself: "[Yiddish] struck vague notes of old outgrown associations but called up no definite images" (202). Father and son are also separated by a gulf in their understanding of his future ambitions: Moses wants him to be a rabbi, and Benjamin wants to be an English writer more famous than Charles Dickens. When Benjamin becomes ill, he and his father are unable to communicate until Benjamin nears death and reverts to a childish state: "He spoke Yiddish, grown a child again. Moses's face lit up with joy. His eldest born had returned to intelligibility. There was hope still then" (275). As Rochelson has argued in her essay, "Language, Gender, and Ethnic Anxiety," Benjamin is to some extent a double for Zangwill in his ambitions to become an author (401). However, Zangwill eliminates Benjamin because of his separation from his Jewish background, whereas Esther represents a fuller version of the Anglo-Jewish writer in her inability to forget her East End past. Very much a product of the realist novel, Esther absorbs both perspectives and discourses, that of the East End and that of the Jewish bourgeoisie.

\section{Esther, Aestheticism, and the Space of the East End}

The novel's second book more closely resembles the bildungsroman but focuses on a female character who represents and learns the importance of the connection of the individual to the collective minority. By choosing a heroine, Zangwill taps into traditional ideas of Jewish femininity and also alludes to the Bible's Book of Esther. Not only is Esther Ansell a realist novelist, but she also becomes a potential savior of her people. ${ }^{7}$ At the same time, Zangwill taps into and reworks traditions in the newly emerging Yiddish literary tradition, particularly the form of a bildungsroman in which the lead character travels from the shtetl to a big city to become enlightened. Zangwill echoes the homecoming that always follows in this Yiddish literary tradition, when the enlightened young Jewish man returns to his shtetl and feels the nostalgia for an imagined authentic Jewish space.

Zangwill borrows the use of symbolism in Yiddish storytelling throughout the novel, but none are so prominent as the name Esther Ansell. Many 
of the characters have meaningful names-including Moses and Malkaand Esther's name refers to the biblical Esther. The novel urges us to take this connection seriously since many of the central scenes happen during Purim. In the Book of Esther, Xerxes, king of Persia, chooses Esther as a replacement for his disobedient wife. Concealing her Jewish background, Esther lives separately from the Jewish people until a prince convinces the king to order the destruction of all unassimilated Jews. At the behest of her cousin Mordecai, Esther reveals her background and implores the king to retract the order and kill the prince instead. Zangwill's decision to name Esther after this story is key in directing the reader what to take away from the novel. The biblical Esther does not immediately accept her duty to save the Jewish people; rather, she hesitates about her connection to a people she has not lived with for years. When her cousin Mordecai urges her to seek out the king, Esther responds that she has not been summoned by the king and that to go to the inner court without being summoned means almost certain death: "I have not been summoned to go to the king these thirty days" (Fox 61). As Michael Fox suggests, Esther initially worries more about her own well-being and feels that she could escape death since her Jewish identity is unknown. Esther Ansell experiences a similar alienation from her Jewish background. As a child, she reads the New Testament and is drawn to the figure of Christ. As an adult, she lives with a middle-class family who yearns "to approximate as much as possible to John Bull without merging in him" (Zangwill 331). When Raphael celebrates the Jewish people, Esther responds, "I was born in the Ghetto, and when you talk of the mission of Israel, silent, sardonic laughter goes through me as I think of the squalor and the misery" (344). Dislocated from their childhood homes, both Esthers assimilate to the ways of their new abodes; in this case, Esther Ansell's residence at the Goldsmiths parallels Esther's position in Xerxes's household. However, just as the biblical Esther saves her people, Zangwill posits Esther Ansell as the potential hope for the Jewish people: that is, the hope of a modernized Jewish culture that neither assimilates nor separates. Like the biblical Esther, who better serves her people as Jew and as Persian queen, Esther is importantly both English and Jewish. She is no longer part of the East End ghetto but has transcended it and returns to it as someone who is both inside and outside. When she returns to the ghetto after living with the Goldsmiths, she is at first shocked by their lifestyle and by the stark poverty, but her feelings change as she spends more time there: "[S]omething in Esther's breast seemed to stir with a strange sense of kinship. The race instinct awoke to consciousness of itself. Dulled by contact with cultured Jews, transformed almost to repulsion by the spectacle of the coarsely prosperous, it leaped into life at the appeal of squalor and misery" (453). The East End imparts to Esther a sense of the community that has been lost by the middle class West End Jews. Yet it's important that Esther is not quite one of them when she returns to the ghetto. 
Esther, for Zangwill, is the union of the East End immigrant and the educated bourgeoisie; she is representative of the potential for the Jewish community to become modernized and anglicized while still remaining Jewish. Unlike Daniel Deronda, who grew up English and subsequently discovers his Jewishness, Esther grows up in the East End and returns after she has developed a wider perspective.

Not only is Children of the Ghetto a reworking of the Book of Esther, it also borrows from tropes in Yiddish literature, particularly what Dan Miron has identified as the nostalgic idealization of the space of the shtetl. The mid to late nineteenth century saw what has been considered the birth of modern Yiddish literature. According to Miron, the archetypal fable of the native's return home can be found as early as eighteenth-century Yiddish dramas and was later featured in the nineteenth-century Yiddish novel (Traveler Disguised 90). Miron's examples include the first Yiddish novel, Aksenfeld's Dos shterntikhl ("The Headband"), and the Hebrew novel Ayit tsavua ("The Hypocrite"). In 1865, Sholem Yankev Abramovitsh published a Yiddish story called "Dos vintshfingerl" (The Magic Ring), which was influenced by this coming-home trope and features a plot similar to the second half of Zangwill's novel. The main character leaves the shtetl to become an enlightened modern, and he returns at the end of the novel only to face the disintegration of his home. In "The Magic Ring," the homecoming scene is darkened because no one recognizes the hero. In 1888, Abramovitsh importantly expanded this story into a longer work, which would span from the late 1830s to the early 1880s and "throw light on Jewish life and discuss the most important problems we face nowadays" (Miron 95). Zangwill takes on this literary trope in the final pages of Esther's return to the East End. When Esther first returns to Whitechapel, her nostalgia is disrupted by a sense of change and foreignness: "There was a sense of blankness in the wanderer's heart, of unfamiliarity in the midst of familiarity. What had she in common with all this mean wretchedness, with this semi-barbarous breed of beings?" (Zangwill 435). Her childhood memories of Whitechapel conflict with the poverty and dirt she faces as an adult returning to the neighborhood. It also disrupts the timelessness that her nostalgia requires: "She studies the posters and the shopwindows - all seemed as of yore. And yet here and there the hand of Time had traced new inscriptions" (435). Esther's return both reinforces and disrupts the timeless ideal of the shtetl, in this case Whitechapel. And yet at the end of the paragraph, we're told that the ghetto itself has stayed the same while Esther has changed:

It was hard to realize that Time's wheel had been whirling on, fashioning her to a woman; that, while she had been living and learning and seeing the manners of men and the cities, the Ghetto, unaffected by her experiences, had gone on in the same narrow rut. A new generation of children had arisen to suffer and sport in room of the old, and that was all. (436) 
The depiction presents a divided portrayal of the East End, simultaneously timeless and changing. Zangwill echoes the division of Yiddish literature in its treatment of the shtetl, seeing it as a premodern, retrograde lifestyle that needs to be supplanted by modernity and yet at the same time idealizing it as a timeless space of authentic Jewishness. Miron has traced this tradition in his essay "The Image of the Shtetl," which he calls the "love-hate" relationship of Yiddish writers with the folkloric element of eastern European Jewry.

Esther's confused nostalgia invokes the nostalgia that opens Children of the Ghetto. Zangwill begins with what he calls a "Proem" that openly links the "London Ghetto" with the shtetls of eastern Europe in a flowery, present-tense style notably different from the prose in the rest of the novel. Zangwill suggests that the everyday poverty and sordidness of the London Ghetto removes it from genres other than realism, but then he yokes this realism with persistence of romance:

Natheless, this London Ghetto of ours is a region where, amid uncleanness and squalor, the rose of romance blows yet a little longer in the raw air of English reality; a world which hides beneath its stony and unlovely surface an inner world of dreams, fantastic and poetic as the mirage of the Orient where they were woven, of superstitions grotesque as the cathedral gargoyles of the Dark Ages in which they had birth. (61)

Zangwill crafts a romantic nostalgia around the idea of a London Jewish ghetto. Here, Zangwill suggests the persistence of an authentic Jewish identity in the midst of pressures to assimilate. Zangwill metaphorically asks us to look for something in addition to his novel's realism, an element of romance and fantasy. Yiddish writers used realism as a means to convey modern values to what they perceived to be a poorly educated, separatist Jewish majority. The new literary movement emerged from the Haskalah, or the Jewish Enlightenment, which sought to modernize and liberalize the Jewish communities across Europe. Although Yiddish and realism were seen as aesthetically inferior, Yiddish writers strategically wrote in these modes as a way to reach a broader Jewish reading public. And yet in the midst of this realism, the writers articulated a romantic nostalgia for an imagined authentic Jewish shtetl. ${ }^{8}$ To a certain extent, this divided approach to realism appears in Zangwill's novel in ways that mirror the budding Yiddish literary tradition. However, Zangwill also locates in nostalgia a protection against complete assimilation and anglicization. Even as he represents the harsh reality of immigrant life in the East End, he highlights the sentimental importance of their daily material life.

In this way, Zangwill's choice of a nostalgic realism responds to latenineteenth century aestheticism, insofar as Esther is a counterexample to an alienated aesthetics embodied in Sidney Graham. Whereas Esther is able to hybridize Englishness and Jewishness, Sidney as aesthete abandons the Jewish people in his pursuit of an art isolated from the real world. The danger posed 
by this perspective is the loss of the Jewish people through assimilation (which Sidney predicts will happen). In the end of the novel, Zangwill deflects Sidney's position by marrying Sidney off to Raphael's sister Addie, a resolution that is dissatisfying in its use of marriage to quash a larger political and social question. Years later, the figure of the Jewish aesthete arises more materially in the figure of Leopold Barstein, who reappears in stories throughout Ghetto Comedies, a series of stories published by Zangwill in 1907. The stories trace Barstein's development over the course of the collection, bringing him to a stronger awareness of his Jewish origin. In the first story, "The Jewish Trinity," Barstein is described as "a Jewish native of that thriving British centre, [who] should have felt proud and happy. But Barstein was young and a sculptor, fresh from the Paris schools and Salon triumphs. He had long parted company with Jews and Judaism" (Ghetto Comedies 105). When Barstein meets a Jewish MP whom he believes to be a devout Jew, "a racial pride he had not known latent in him surged up through all his cosmopolitanism" (110). He comes to this internal awakening through imagining Sir Asher carefully enacting Jewish rituals: "There came to him a touch of new and artistic interest in this prosy, provincial ex-M.P., who, environed by powdered footmen, sat at the end of his glittering dinner-table uttering the language of the ancient prophets" (109). His awakening remains despite his discovery that the MP is a hypocrite and embodies what Barstein calls the "Jewish trinity": "The Briton, the Jew, and the anti-Semite - three-in-one and one-in-three" (135). Barstein is inspired to leave off his cosmopolitan and aesthetic perspective in order to become an artist in touch with a Judaic past and a Zionist future. Zangwill suggests that even as the aesthete claims to disown the real, he is actually capitulating to assimilation and abandoning his community.

Zangwill published Children of the Ghetto just two years after Oscar Wilde's The Picture of Dorian Gray. One of the preeminent works of aestheticism, Dorian Gray provides a stark, one-dimensional portrayal of the East End and its Jewish population. Children of the Ghetto is in part a response to Wilde's only novel, and it centrally thematizes aestheticism in order to suggest its shortfalls in relation to the problems encountered by Anglo-Jews. Sidney Graham inverts Dorian Gray's double life. Dorian Gray lives his respectable existence in London's West End and then revels in debauchery in the East. He begins his double life when he visits a playhouse in the East End, where he meets a Jewish stage manager and a young Jewish actress with whom he falls in love and later abandons. The Jewish stage manager is a stock melodramatic figure and is described by Dorian as a "monster" and as the most "hideous Jew, in the most amazing waistcoat I ever beheld in my life" (47-48). In contrast, Sidney seeks the West End for his second life, where he denies his Jewish heritage and is engaged to a Christian woman unbeknownst to his family.

Zangwill plays with the plot of Wilde's novel to suggest the extent to which it leaves out the Jews and fails to imagine another kind of double life. 
Indeed, the East End becomes a place of sexual license, where Dorian Gray can conceal his identity and West End reputation. By the end of the nineteenth century, slumming had become a common practice, whether it was done to experience sexual and social freedom or for philanthropic purposes. The space of the East End operates much like the variable figure of the Jew, serving as an empty container for anything opposed to the West End. Many scholars, such as Judith Walkowitz and Seth Koven, have highlighted the extent to which the East End was exoticized as an imperial outpost within the domestic city. Zangwill counters this interpretation by a marked focus on place in the structure of his novel, evidenced even in its title. As I argued earlier in this paper, Zangwill allows the narrative to move more spatially than temporally, as his narrator guides the reader around the East End and offers glimpses of the Petticoat Lane market and the tenement houses. Whereas for Wilde the East End is an indeterminate space of sexual freedom, Zangwill highlights and idealizes the centrality of the space of the ghetto to retaining Jewish identity in a modern world. His "Proem" compares the London ghetto to "the olden Ghetto of the Eternal City." Despite the ethnic variety of Victorian London's East End, Zangwill portrays it as a "Ghetto" that is almost purely Jewish. Rather than being disrupted by non-Jewish residents, the London ghetto passes away because its Jewish inhabitants slowly leave and disperse into a greater world: "For better or for worse, or for both, the Ghetto will be gradually abandoned, till at last it becomes only a swarming place for the poor and the ignorant, huddling together for social warmth" (62). Zangwill's proem expresses nostalgia for the separate life that he imagines the London ghetto formerly offered and increasingly does not. He misses the days when the Jewish upper class lived in the same neighborhood as "aristocrats of the Ghetto" and gave charity in "the same Oriental, unscientific, informal spirit in which the Dayanim, those cadis of the East End, administered justice" (62). Zangwill imagines a past when England's Jewish community was self-supportive and coherent within the East End, when the wealthy happily supported the poor, in contrast to the realist text that then follows this proem. Zangwill importantly here mingles nostalgia and realism. Zangwill responds to Wilde's murky depiction of the East End with an idealized version of his own that, as I've already suggested, draws upon eastern European representations of the shtetl. This juxtaposition suggests the limited perspective of the cosmopolitan aesthete and Wilde's relegation of the East End and the Jews to melodrama and crime.

\section{Conclusion: Zangwill, Realism, and Zionism}

The realist form for Zangwill embodies his ideal of a melting pot of different peoples, not one in which everyone fuses into a homogeneous group, but one that fosters difference. Children of the Ghetto does not end with a Zionist vision, as does Daniel Deronda, but the promise of America. Rather than ending with a marriage, the novel's final scene features Esther leaving 
Raphael and boarding a ship bound for America: "With a sudden fit of nervous foreboding she stretched out her arms towards the vanishing figure of her lover. But she saw him once again in the tender, waving his handkerchief towards the throbbing vessel that glided with its freight of hopes and dreams across the great waters towards the New World" (502). Much later in his career, Zangwill would celebrate the potential of America to bring together diverse peoples and coin the term "The Melting Pot" in a 1905 play of the same name. He argued that America represented the tenor of Jewish culture. According to Edna Nahshon, "Zangwill's rhetoric of immigration is embedded in the Exodus saga....He thus bestows upon America and its people the glory of being providentially guided, party to a divine covenant" (212). In a sense, America offers the possibility of a new "ghetto" that is more financially secure; it is as diverse as London's East End, but also offers a place for Jewish identity.

Whereas Deleuze and Guattari argue that Kafka deterritorializes the German language in his writings, I am arguing that Israel Zangwill paradoxically mingles the English and Jewish forms of communication in Children of the Ghetto. He creates connections where others see none and crafts synonyms out of seeming antonyms. He complicates and nuances ideas of national identity to the point of paradox and, possibly, nonsense. Many critics have highlighted how strongly Zangwill associates with his English identity, and yet he expressed it in semantically peculiar ways: he said, "I am a Jew, of course, and I am proud of it. But I am not an alien. I am a pure Cockney" (qtd. in Leftwich 141). Rather than affiliating with a middle-class Englishness here, he rejects his alien status by claiming a Cockney identity that offers a particular type of Englishness, one often viewed as alien by a subset of the Victorian population. And he isn't just Cockney - he says he's pure Cockney, a paradoxical claim about a term that describes working-class Londoners. Zangwill imagines a space where being purely Jewish, purely Cockney, and purely English is possible, and he playfully distorts what it means to be pure.

\section{UNIVERSITY OF HONG KONG}

\section{NOTES}

${ }^{1}$ For instance, Zangwill is referred to as "The Dickens of the Ghetto" in an 1895 column in the San Francisco Call.

2 Wisse adds, "By now in the history of culture and politics, a warning bell should toll whenever a social scientist, cultural critic, or politician exploits the word Jew to mean the man without a country and turns him into the standard-bearer of yet another theory of 'deterritorialization''internationalism' or evaporation by a subtler name" (87).

${ }^{3}$ Critics like Susan David Bernstein have read Mordecai Josephs as either an anticipatory satire of the potential reception of Children of the Ghetto or an indictment of the 1888 public reception of Amy Levy's Reuben Sachs. These popular and persuasive readings do not conflict with my own reading. 
${ }^{4}$ In her discussion of Dracula, Melissa Olson emphasizes that Victorians used phrenology to justify anti-Semitic stereotypes. Phrenology and physiognomy were used to link Jewish features with hereditary criminality and degeneration (32).

${ }^{5}$ In fact, Naomi Hetherington argues, "Children of the Ghetto does not promote a new Jewish faith in the way that Robert Elsmere reinvents Christianity with the hero's founding of the New Brotherhood of Christ" (191).

${ }^{6}$ Yet although Zangwill borrows associative organization from Yiddish literature, particularly for his first book in the novel, he differs in one important aspect: an impersonal narrator describes the East End, whereas Tevye the Dairyman is narrated by a character using associative storytelling.

${ }^{7}$ Zangwill's use of Esther as a hybrid ideal draws upon stereotypical nineteenth-century portrayals of Jewish women as more susceptible to reform than their male counterparts. Zangwill uses the conversion discourse surrounding the Jewess to substantiate Esther's elevation to an ideal (Ragussis)

${ }^{8}$ Dan Miron makes this argument in his essay "The Image of the Shtetl." Examples of Yiddish writers who idealize the shtetl and represent it as a purely Jewish space include Sholem Aleichem and his fictional town Kasrilevke as well as Y. L. Peretz and his towns in Bilder fun a provints rayze ("Image of the Shtetl" 4).

\section{WORKS CITED}

Anderson, Benedict. Imagined Communities: Reflections on the Origin and Spread of Nationalism. New York: Verso, 2006.

Bernstein, Susan David. Introduction. Reuben Sachs: a Sketch. New York: Broadview, 2006.

Bar-Yosef, Eitan, and Nadia Valman. 'The Jew'in Late-Victorian and Edwardian Culture Between the East End and East Africa. New York: Palgrave, 2013.

Caplan, Marc. How Strange the Change: Language, Temporality, and Narrative Form in Peripheral Modernisms. Palo Alto: Stanford UP, 2011.

David Cesarani. The Jewish Chronicle and Anglo-Jewry, 1841-1991. New York: Cambridge UP, 1994.

Cheyette, Bryan. "Englishness and Extraterritoriality: British-Jewish Writing and Diaspora Culture." Literary Strategies: Jewish Texts and Contexts. Studies in Contemporary Jewry. Ed. Ezra Mendelsohn. New York: Oxford UP, 1996.

Childers, Joseph. "At Home in Empire." Homes and Homelessness in the Victorian Imagination. Ed. Murray Baumgarten and Hillel Matthew Daleski. New York: AMS, 1998. 215-26.

Deleuze, Gilles, and Felix Guattari. Kafka: Toward a Minor Literature. Trans. Dana Polan. Minneapolis: U of Minnesota P, 1986.

Eliot, George. Adam Bede. New York: Penguin, 2008.

Elzas, Emanuel. "Israel Zangwill - A Sketch." San Francisco Call. 25 Aug. 1895.

Feldman, David. Englishmen and Jews: Social Relations and Political Culture, 1840-1914. New Haven: Yale UP, 1994.

Fox, Michael. Character and Ideology in the Book of Esther. Eugene, OR: Wipf and Stock, 2010.

Gates, Sarah. "“A Difference of Native Language': Gender, Genre, and Realism in Daniel Deronda." ELH 68.3 (2001): 699-724.

Gilman, Sander L. Inscribing the Other. Lincoln: U of Nebraska P, 1991.

Glover, David. "Imperial Zion: Israel Zangwill and the English Origins of Territorialism." The Jew in Late-Victorian and Edwardian Culture: Between the East End and East Africa. Ed. Eitan Bar-Yosef and Nadia Valman. New York: Palgrave, 2009.

Harshav, Benjamin. The Meaning of Yiddish. Palo Alto: Stanford UP, 1999.

-. "The Semiotics of Yiddish Communication." What is Jewish Literature. Ed. Hana WirthNesher. Philadelphia: Jewish Publication Society, 1994.

Hetherington, Naomi. “'A Jewish Robert Elsmere'?: Amy Levy, Israel Zangwill, and the Postemancipation Jewish Novel." Amy Levy: Critical Essays. Ed. Nadia Valman and Naomi Hetherington. Athens: Ohio UP, 2010.

"Jews in Fiction VI: Fagin and Riah." Jewish Standard. 20 Apr. 1888. 
Koven, Seth. Slumming: Social and Sexual Politics in Victorian London. Princeton: Princeton UP, 2004.

Leftwich, Joseph. Israel Zangwill. New York: Thomas Yoseloff, 1957.

Levy, Amy. The Complete Novels and Selected Writings of Amy Levy, 1861-1889. Ed. Melvyn New. Gainesville, FL: UP of Florida, 1993.

Miron, Dan. The Image of the Shtetl and Other Studies of Modern Jewish Literary Imagination. Syracuse: Syracuse UP, 2001.

-. Introduction. Tevye the Dairyman and Motl the Cantor's Son. New York: Penguin, 2009.

-. A Traveler Disguised: A Study in the Rise of Modern Yiddish Fiction in the Nineteenth Century. New York: Shocken Books, 1973.

Moretti, Franco. The Way of the World: The Bildungsroman in European Culture. New York: Verso, 1987.

Nahshon, Edna. From the Ghetto to the Melting Pot: Israel Zangwill's Jewish Plays. Detroit: Wayne State UP, 2006.

Olson, Melissa. "Dracula the Anti-Christ: New Resurrection of an Immortal Prejudice." Images of the Modern Vampire: The Hip and the Atavistic. Ed. Barbara Brodman and James E. Doan. Lanham, Maryland: Rowman and Littlefield, 2013.

Ragussis, Michael. Figures of Conversion: 'The Jewish Question' and English National Identity. Durham: Duke UP, 1995.

Rochelson, Meri-Jane. "The Big Bow Mystery: Jewish Identity and the English Detective Novel." Victorian Review 17.2 (1991): 11-20.

-. A Jew in the Public Arena: The Career of Israel Zangwill. Detroit: Wayne State UP, 2008.

-. "Language, Gender, and Ethnic Anxiety in Zangwill's Children of the Ghetto." English Literature in Transition, 1880-1920 31.4 (1988): 399-412.

—. "'Religion of Pots and Pans': Jewish Materialism and Spiritual Materiality in Israel Zangwill's Children of the Ghetto." Victorian Vulgarity: Taste in Verbal and Visual Culture. Ed. Susan David Bernstein and Elsie B. Michie. Burlington, VT: Ashgate, 2009. 119-35.

- "Zionism, Territorialism, Race, and Nation in the Thought and Politics of Israel Zangwill." The Jew in Late-Victorian and Edwardian Culture Between the East End and East Africa. Ed. Eitan Bar-Yosef and Nadia Valman. New York: Palgrave, 2009.

Udelson, Joseph. Dreamer of the Ghetto: The Life and Works of Israel Zangwill. Tuscaloosa, AL: U of Alabama P, 1990.

Valman, Nadia. The Jewess in Nineteenth-Century British Literary Culture. Cambridge: Cambridge UP, 2007.

Walkowitz, Judith. City of Dreadful Delight: Narratives of Sexual Danger in Late-Victorian London. Chicago: U of Chicago P, 1992.

Williams, Bill. "The Anti-Semitism of Tolerance: Middle-class Manchester and the Jews." City, Class and Culture: Studies of Social Policy and Cultural Production in Victorian Manchester. Ed. A. J. Kidd and K. W. Roberts. Manchester, 1985.

Wilde, Oscar. Complete Works of Oscar Wilde. 3rd ed. Glasgow: Harper, 1994.

Wisse, Ruth. The Modern Jewish Canon: A Journey through Language and Culture. New York: Free Press, 2000.

Zangwill, Israel. Children of the Ghetto: A Study of a Peculiar People. Detroit: Wayne State UP, 1998.

—. Ghetto Comedies. New York: Grosset and Dunlap, 1909.

—. "Morour and Charouseth." Jewish Standard. 26 Sept. 1890: 10. 
Copyright of Studies in the Novel is the property of University of North Texas and its content may not be copied or emailed to multiple sites or posted to a listserv without the copyright

holder's express written permission. However, users may print, download, or email articles for individual use. 